\title{
Analisa Kinerja Usaha Pemasaran Pakan Ayam Pada Rajawali Feed Centre Padang
}

\author{
Fitrini \\ Jurusan Produksi Ternak Fakultas Peternakan Universitas Andalas \\ Kampus Limau Manis Padang
}

\begin{abstract}
The aims of the present research were to evaluate the management and finacial performance of poultry shop. Data or information were directly collecetd by visiting and interviewing of Rajawali Feed Centre Padang. Data collected included: daily management practices, kinds of produk sold, cost of handling, transport dan storage and organization cost. Finacial data were analyzed for Current Ratio, Quick Ratio, Solvability Ratio and Sales Turn Over.Results showed that Rajawali Feed Centre basicly have a good financing and management performance. Financing performance (Current Ratio $=298,13 \% ;$ Quick Ratio $=111,80 \% ;$ Solvability Ratio $=500 \%$ and Sales Turn Over $=23,20$ ). According to financing and management performance analysis of this business, Rajawali Feed Centre have a good development prospect.
\end{abstract}

Key words: poultry shop; curren, quick ratio and sovability ratio; sale turn over.

\section{Pendahuluan}

Rajawali Feed Centre merupakan salah satu distributor pakan ayam di Kota Padang, terutama yang diproduksi oleh perusahaan PT. Charoen Pokphan Medan, Indonesia. Sebagai suatu bisnis, usaha ini terus mengalami perkembangan semenjak didirikan pada tahun 1996, terbukti mulai tahun 2000 Rajawali Feed Centre terus menambah wilayah pemasarannya di daerah Sumatera Barat (dapat dilihat pada Tabel 1).

Sejalan dengan peningkatan perkembangan usaha peternakan ayam, kebutuhan peternak terhadap pakan tentunya juga terus bertambah. Tercatat pada BPS bahwa jumlah ternak unggas di Kota Padang saat ini semakin bertambah yaitu untuk tahun 2004; ayam buras sebanyak 448.091 ekor, ayam ras pedaging 4.854 .900 ekor dan, ayam ras petelur 516.400 ekor, sedangkan pada tahun 2003 jumlah ayam pedaging sebesar 3.650 .000 dan ayam petelur sebesar 400.800 (BPS 2004). Sedangkan untuk daerah Sumbar tahun 2004 jumlah ayam pedaging sebesar 12.804.118, pada tahun 2003 berjumlah 10.608.542. Hal ini merupakan suatu kesempatan baik bagi Rajawali Feed Centre sebagai distributor pakan ayam.

Kemampuan untuk meraih dan memanfaatkan peluang permintaan pakan yang ada, haruslah direncanakan dengan baik oleh Rajawali Feed Center. Perencanaan harus mempertimbangkan berbagai aspek antara lain meliputi aspek keuangan, teknis, sumberdaya manusia dan pemasaran. Untuk menilai keberhasilan atau kegagalan perencanaan /kegiatan perusahaan digunakan pengukuran kinerja.

Hasil penilaian kinerja digunakan dalam menentukan tingkat 
kesehatan perusahaan, agar dapat diketahui tingkat keberhasilan suatu usaha dalam mencapai tujuan yang telah ditetapkan. Penilaian kinerja dilakukan berdasarkan data dan informasi keuangan dan non-keuangan.

Menurut Rangkuti (1997) dari kinerja keuangan tersebut terlihat seberapa jauh manajemen dapat mengelola sumber daya keuangan. Pada umumnya, pengelolaan keuangan yang tidak baik menyebabkan usaha yang bersangkutan berantakan. Cara yang paling cepat untuk mengukur kinerja keuangan perusahaan adalah dengan melakukan analisis ratio.

Disamping kinerja keuangan, tingkat keberhasilan usaha juga dapat ditentukan dari kinerja manajamen meliputi aspek teknis, sumberdaya manusia dan pemasaran.

Berdasarkan analisa kinerja keuangan dan manajemen tersebut diharapkan nanti dapat diketahui prospek pengembangan usaha pemasaran pakan ayam yang dilakukan oleh rajawali Feed Centre Padang.

Tujuan penelitian ini adalah untuk mengevaluasi kinerja perusahaan ditinjau dari aspek keuangan dan manajemen serta prospek pengembangan usaha Rajawali Feed Centre Padang.

\section{Materi Dan Metode}

Penelitian ini dilaksanakan pada Rajawali Feed Centre yang berlokasi di jalan By Pass No. 5 Lubuk Begalung Padang melalui metode studi kasus untuk memberikan gambaran secara mendetail tentang latar belakang, sifat, karakter yang khas dari kasus (Nazir, 1983). Data yang diambil dalam penelitian ini adalah data primer dan data sekunder. Data primer diperoleh melalui pengamatan langsung dan melalui wa-wancara dengan pimpinan perusahaan dengan menggunakan daftar per-tanyaan yang telah disediakan. Data sekunder diperoleh dari instansi - instansi pemerintah yang terkait dengan penelitian ini.

Adapun data yang diamati pada penelitian ini meliputi :

\section{Kinerja keuangan}

Untuk penilaian terhadap kinerja keuangan dilakukan dengan analisis ratio, yakni rasio likuiditas, solvabilitas, dan aktivitas. Data yang dibutuhkan berkaitan dengan aktiva dan pasiva perusahaan.

\section{Kinerja Manajemen}

Penggambaran terhadap kinerja manajemen ini lebih kualitatif dengan melakukan analisis manajemen, meliputi :

a). Aspek Teknis

Meliputi cara pemesanan barang dan waktu barang datang, fasilitas operasi, dan aktivitas perusahaan.

b). Aspek Sumber Daya Manusia Meliputi struktur organisasi perusahaan, efisiensi jumlah tenaga kerja, cara pengrekrutan, hari dan waktu kerja, tingkat pendidikan tenaga kerja.

c). Aspek Pemasaran

Terdiri dari kebijakan pemasaran yang dilakukan perusahaan, meliputi produk, harga, distribusi dan promosi.

Untuk mengetahui kinerja perusahaan maka dilakukan analisa terhadap kinerja keuangan dan kinerja manajemen.
1. Kinerja keuangan
Untuk penilaian terhadap kinerja keuangan dilakukan dengan analisis ratio, yakni rasio likuiditas, solvabilitas, 
dan aktivitas. Analisis laporan keuangan untuk mengetahui kinerja dan perkembangan usaha ini dilakukan terhadap:

a). Likuiditas

Yaitu digunakan untuk menganalisa dan menginterpretasikan posisi keuangan dalam jangka pendek

(i) Rasio lancar (Current ratio)

Yakni menunjukkan tingkat kemampuan perusahaan untuk membayarkan hutang jangka pendek

Rasio lancar $=$ Aktiva lancar $\times 100 \%$

$$
\text { Hutang lancar }
$$

Standar nilai yang baik untuk rasio lancar ini adalah 2:1 atau sama dengan $200 \%$ (Munawir, 1993)

(ii) Rasio cepat (acid test ratio (quick ratio)

Yakni menunjukkan kemampuan perusahaan dalam memenuhi kewajiban-kewajiban

Rasio yang segera harus dipenuhi.

cepat $=$ Aktiva lancar-persediaan $\times 100 \%$ Hutang lancar

Standar nilai yang baik untuk rasio cepat adalah $1: 1$ atau sama dengan $100 \%$ (Munawir, 1992)

b). Solvabilitas

Yaitu untuk menganalisa dan menginterpretasikan posisi keuangan dalam jangka panjang dan jangka pendek.

(iii)Rasio modal sendiri dengan total aktiva

Yakni perbandingan antara jumlah modal sendiri dengan total aktiva.

Rasio modal sendiri dengan total aktiva $=$ Modal sendiri $\times 100 \%$

Total aktiva
Standar nilai yang baik untuk rasio ini adalah $50 \%$ (Munawir, 1993)

(iv)Rasio modal perbandingan sendiri dengan aktiva tetap

Yakni perbandingan antara modal sendiri dengan aktiva tetap yang dimiliki.

Rasio modal sendiri dengan aktiva tetap $=$ Modal sendiri $\times 100 \%$

\section{Total aktiva}

Standar nilai yang baik untuk rasio ini adalah $100 \%$ (Munawir, 1993)

c). Aktivitas

Menunjukkan efisiensi perusahaan dalam mengelola sumber daya yang dimilikinya untuk memperoleh penjualan.

Perputaran aktiva $=$ penjualan total aktiva

Standar nilai yang baik untuk menunjukkan perputaran aktiva ini adalah 2,5 kali.

\section{Kinerja Manajemen}

Analisa data dilakukan secara deskriptif kualitatif terhadap aspek teknis, sumberdaya manusia dan pemasaran yang dilakukan perusahaan selama ini.

\section{Hasil Dan Pembahasan}

\section{Profil Perusahaan}

Usaha pemasaran pakan ayam Rajawali Feed Centre ini didirikan pada tahun 1996. Usaha ini terletak di Jalan By Pass No. 5 kelurahan Lubuk Begalung Padang. Pada tahun 1996 usaha ini didirikan sebagai usaha keluarga yang dipimpin langsung oleh Bapak Yasril Islami. Pada tahun 2000 Bapak Yasril Islami mulai meningkatkan permodalan melalui lembaga perbankan. Rajawali Feed Centre dalam usahanya bekerjasama dengan PT. Charoen Pokphan sebagai 
pemasok tunggal pakan ayam. Daerah pemasaran pada Rajawali Feed Centre ini terus bertambah sejak tahun 2000 . Saat ini Rajawali Feed Centre sudah memiliki \pm 10 dacrah pemasaran pakan ayam (Tabel 1).

Rajawali Feed Centre saat ini memiliki 8 buah alat transportasi, dari sarana yang dimiliki diharapkan supaya kegiatan pemasaran ke daerah - daerah dapat berjalan dengan baik. Walaupun terkadang terjadi beberapa kendala dalam pengirimannya namun Rajawali Feed Centre selalu berusaha untuk tidak mengecewakan konsumen dengan tetap tepat waktu. Hingga saat ini Rajawali Feed Centre telah menyewa 2 buah gudang. Gudang 1 berlokasi tepat disebelah toko
Rajawali Feed Centre sedangkan gudang II terletak $\pm 250 \mathrm{~m}$ dari usaha tersebut. Surat izin usaha yang digunakan sekarang berlaku dari tahun 2005 hingga 2008, dengan no izin usaha yaitu Nomor:503. 806/SITU/EK VI/2005.

Tabel 1 menunjukkan adanya perkembangan pemasaran setiap tahunnya yang dilakukan oleh Rajawali Feed Centre. Penjualan di luar daerah lebih dimanfaatkan oleh Rajawali Feed Centre, karena peluang pasarnya masih lebih besar dan memungkinkan untuk dimasuki, dengan berbandingan penjualan di luar daerah dan di dalam Kota Padang 70 : 30.

Tabel 1. Perkembangan Daerah Pemasaran Pakan Ayam Pada Rajawali Feed Centre Padang Tahun 2000-2005

\begin{tabular}{cl}
\hline Tahun & \multicolumn{1}{c}{ Daerah Pemasaran } \\
\hline 2000 & Padang, Sungai Penuh \\
2001 & Padang, Sungai Penuh, Painan, Pariaman \\
2002 & Padang, Sungai Penuh, Painan, Pariaman, Solok \\
2003 & Padang, Sungai Penuh, Painan, Pariaman, Solok, Payakumbuh \\
2004 & $\begin{array}{l}\text { Padang, Sungai Penuh, Painan, Pariaman, Solok, Payakumbuh, Jambi, } \\
\text { Riau, Pasaman }\end{array}$ \\
2005 & $\begin{array}{l}\text { Padang, Sungai Penuh, Painan, Pariaman, Solok, Payakumbuh, Jambi, } \\
\text { Riau, Pasaman }\end{array}$ \\
\hline
\end{tabular}

Tabel 2. Volume Penjualan Pakan Ayam Pada Rajawali Feed Centre Padang Tahun $2000-2005(000,-\mathrm{Kg})$

\begin{tabular}{cccc}
\hline Tahun & $\begin{array}{c}\text { Target Penjualan } \\
(1)\end{array}$ & $\begin{array}{c}\text { Realisasi Penjualan } \\
(2)\end{array}$ & $\begin{array}{c}\text { Persentase Realisasi } \\
\text { atas target } \\
(3)\end{array}$ \\
\hline 2000 & 3.600 & 2.640 & 73,3 \\
2001 & 3.600 & 3.000 & 83,3 \\
2002 & 7.200 & 3.060 & 42,5 \\
2003 & 9.600 & 8.400 & 87,5 \\
2004 & 12.000 & 9.600 & 80 \\
2005 & 24.000 & 20.000 & 83,3 \\
\hline
\end{tabular}


Dari tabel diatas dapat dilihat adanya peningkatan penjualan setiap tahunnya dari Rajawali Feed Centre. Hal ini dapat menunjukkan kemampuan perusahaan dalam meningkatkan usahanya. Pada tahun 2005 terjadi pelonjakkan penjualan cukup besar dikarenakan besarnya permintaan pasar pada tahun tersebut.

\section{Kinerja Ketuangan}

Dalam penelitian ini, analisa keuangan dilakukan dengan menggunakan analisa-analisa rasio.

\section{a. Rasio Likuiditas}

Rasio likuiditas menggambarkan kemampuan perusahaan untuk menyelesaikan kewajiban jangka pendek, yang terdiri dari Current Rasio dan Quick Rasio dengan ukuran standar yaitu 100-200 \% (Munawir, 1993). Dari hasil perhitungan yang didapat menyatakan bahwa Rajawali Feed Centre berada pada posisi yang likuid dimana Current Rasio dan Quick Rasio pada perusahaan bernilai besar diatas ukuran standar yaitu sebesar $298,13 \%$ dan 111,80 $\%$, artinya dapat mudah melakukan pembayaran seluruh utang perusahaan.

b. Rasio Solvabilitas

Rasio solvabilitas mengukur kemampuan perusahaan dalam memenuhi kewajibannya pada saat likuid. Pada Rajawali Feed Centre nilai rasio solvabilitas atas rasio modal sendiri dengan total aktiva hanya sebesar 23,20\% dibawah standar (50 \%). Rangkuti (1997) mengatakan rasio $<0,75$ berarti perusahaan tidak dapat menutup hutang lancarnya. Pada perusahaan Rajawali Feed Centre, hal ini tidak berarti perusahaan tidak likuid, karena perusahaan menerapkan kebijakan uang kas yang ada di perusahaan hanya untuk operasional perusahaan, selebihnya diinvestasikan pada aktiva/persediaan. Sedangkan rasio modal sendiri dengan aktiva tetap menunjukkan nilai besar dari nilai standar yaitu $500 \%$ yang menyatakan bahwa perusahaan cukup solvabel dalam memenuhi kewajibannya saat likuid.

c. Rasio Aktivitas

Rasio aktivitas mengukur seberapa efektif perusahaan dalam menggunakan sumber dayanya. Terdiri dari Salles Turn Over, semakin cepat perputaran aktiva, akan semakin baik bagi perusahaan. Dari hasil perhitungan yang diperoleh bahwa didapatkan keseluruhan perputaran aktiva ini selama setahun adalah 23,20 kali.

\section{Kinerja Manajemen}

1). Aspek Teknis

Aspek teknis berkaitan dengan aktivitas mempelajari bagaimana secara teknis proses produksi dilaksanakan. Yaitu diantaranya, toko dan penggudangan, cara pemesanan dan waktu datangnya barang, serta aktivitas perusahaan.

a). Toko dan Penggudangan

Rajawali Feed Centre menyewa toko yang berlokasi di J. By Pass No. 10 Kelurahan Tanjung Saba Lubuk Begalung Padang dengan luas tempat usaha/toko $120 \mathrm{M} 2$ yang digunakan sebagai tempat melakukan aktivitas perusahaan termasuk diantaranya jual beli.

Selain bangunan toko yang ada, Rajawali Feed Centre Padang juga menyewa dua bangunan penggudangan.Gudang pertama terletak disebelah toko sebagai gudang penjualan, sedangkan gudang kedua terletak $\pm 250 \mathrm{~m}$ dari lokasi toko, yang berperan sebagai gudang utama untuk penyimpanan pakan yang baru tiba. 
Penggudangan termasuk ke dalam fungsi pengadaan fisik dalam fungsi pemasaran.

\section{b). Aktivitas Perusahaan}

Suatu perusahaan yang telah dibentuk atau didirikan mempunyai tujuan. Dan untuk mencapai tujuan tersebut perusahaan harus melakukan suatu aktivitas atau kegiatan agar mencapai suatu kesuksesan. Kesuksesan tersebut dapat dicapai dengan melakukan teknik - teknik yang dilakukan perusahaan seperti mencari peluang-peluang baru dalam memasarkan barang dan juga menentukan barang-barang yang baik dan seefisien mungkin.

Rajawali Feed Centre sebagai salah satu distributor pakan ayam, menyalurkan barang-barang dari perusahaan ke daerah pemasaran yang dituju. Rajawali Feed Centre melakukan pemesanan pada pemasok secara rutin dua kali dalam seminggu. Hal ini dilakukan untuk menjaga agar tidak terjadi kekosongan stok pakan dalam gudang, stok harus ada di gudang minimal 10 ton. Pakan ayam termasuk barang konsumsi bagi ternak dan mempunyai batas kadaluwarsa, pakan ayam hanya boleh maksimal dua bulan berada di dalam gudang, dan harus segera dikeluarkan.

Barang-barang dari pemasok mempunyai jangka waktu $2-4$ hari dari waktu pemesanan untuk dapat sampai pada Rajawali Feed Centre. Hal tersebut tergantung dari ekspedisi yang digunakan, yaitu ekspedisi melalui pekanbaru atau medan. Pada usaha distributor pakan ayam Rajawali Feed Centre menggunakan ekspedisi melalui Pekan baru.

\section{2). Aspek Sumber Daya Manusia}

Dalam aspek sumber daya manusia yang perlu diperhatikan yaitu struktur organisasi perusahaan, jumlah tenaga kerja dan tingkat pendidikan tenaga kerja.

a). Struktur Organisasi

Dalam suatu organisasi dengan segala aktivitasnya, terdapat hubungan diantara orang - orang yang menjalankan aktivitas tersebut. Makin banyak kegiatan yang dilakukan dalam suatu organisasi, akan makin kompleks pula hubungan-hubungan yang ada. Untuk keperluan itulah dibuat suatu bagan yang menggambarkan tentang hubungan tersebut, termasuk hubungan antara masing-masing kegiatan atau fungsi. Bagan yang dimaksud dikenal dengan bagan organisasi atau struktur organisasi.

\section{b). Tenaga Kerja}

Sumber daya manusia merupakan unsur terpenting dalam suatu usaha, yang berkaitan dengan penyediaan tenaga kerja bagi pengelolaan usaha dan kelangsungan produksi suatu usaha. Tenaga kerja yang dimaksud disini meliputi pemilik usaha/pengusaha dan para pekerja yang terdapat pada usaha pemasaran pakan ayam Rajawali Feed Centre.

Usaha pemasaran Rajawali Feed Centre Padang mempunyai 5 orang tenaga kerja tetap dan 30 orang tenaga kerja tidak tetap. Dimana 5 orang tenaga kerja tetap terdiri dari 1 orang pemilik sekaligus pimpinan, 1 orang tenaga internal audit, 1 orang tenaga penjualan, 1 orang tenaga keuangan dan administrasi, dan 1 orang tenaga bagian gudang. Sedangkan untuk 30 orang tenaga kerja tidak tetap termasuk didalamnya tenaga sopir dan tenaga angkut.

Perekrutan tenaga kerja umumnya melalui penyampaian secara mulut ke mulut, tidak melalui pengiklanan sehingga sistem tenaga kerja yang ada pada Rajawali Feed Centre lebih bersifat kekeluargaan. 
Menurut Husein Umar (2002) bahwa proses rekruitmen pencari kerja dengan kualifikasi tidak memadai akan memperbesar risiko terhadap kinerja perusahaan kelak. Di banyak perusahaan sampai sekarang, pencarian tenaga kerja perusahaan dikelola dengan kurang baik. Hal ini sebagian disebabkan oleh adanya pertimbangan-pertimbangan pribadi serta sulitnya penilaian secara efektif.

Husein Umar (2002) mengatakan bahwa pelatihan dan pelatihan ulang perlu dilakukan jika perusahaan harus mengembangkan tenaga kerja yang sanggup memproduksi barangbarang dan pelayanan-pelayanan yang dapat berubah dengan cepat. Namun sebagai suatu perusahan distributor pakan ayam yang juga menyadari pentingnya sumber daya manusia, Rajawali Feed Centre belum dapat memberikan pelatihan yang diperlukan bagi karyawannya.

Untuk meningkatkan produktivitas tenaga kerja Rajawali Feed Centre mengadakan penilaian prestasi tenaga kerja yang dilakukan setiap bulan/tahun dan memberikan imbalan sebagai bonus kerja bagi karyawannya. Hal ini dimaksudkan Rajawali Feed Centre untuk memotivasi produktifitas dan menjalin hubungan baik dengan tenaga kerja.

Tingkat pendidikan karyawan pada usaha distributor pakan ayam Rajawali Feed Centre dapat dilihat pada Tabel 3.

3). Aspek Pemasaran
Aspek pemasaran yang diukur pada penelitian ini terdiri dari kebijakan pemasaran yang dilakukan perusahaan, mencakup empat bauran pemasaran, yaitu produk yang ditawarkan, harga produk, sistem distribusi, dan promosi.

a). Produk

Produk adalah barang atau jasa yang bisa ditawarkan di pasar untuk mendapatkan perhatian, permintaan, pemakaian, atau konsumsi yang dapat memenuhi keinginan atau kebutuhan. Pada Rajawali Feed Centre Padang produk yang ditawarkan adalah pakan ternak diantaranya termasuk pakan ternak ikan dan ternak burung, sebagai produk utama adalah pakan ternak ayam yang diambil dari PT. Charoen Pokphan Medan. Rajawali Feed Centre Padang menawarkan berbagai jenis pakan ayam yang diperlukan bagi ternak ayam dari umur sehari (Day Old Chik) hingga pakan ternak ayam yang telah afkir. Sebagai distributor Rajawali Feed Centre menjual pakan ayam ternak dengan harga grosiran (perkarung/per $50 \mathrm{~kg}$ ), dan bagi konsumen yang berlokasi dekat dengan toko Rajawali Feed Centre Padang atau yang terbiasa membeli langsung, Rajawali Feed Centre juga menyediakan harga eceran (per $1 \mathrm{~kg}$ ). Berikut pada Tabel 4 bisa dilihat jenis-jenis pakan ayam pada Rajawali Feed Centre Padang.

Tabel 3. Tingkat Pendidikan Tenaga Kerja Rajawali Feed Centre Padang

\begin{tabular}{ccc}
\hline No. & Tingkat Pendidikan & Jumlah (orang) \\
\hline 1. & D3 & 3 \\
2. & SMA & 17 \\
3. & SMP & 9 \\
4. & SD & 7 \\
\hline
\end{tabular}


Tabel 4. Jenis Pakan Yang Dijual Pada Rajawali Feed Centre Padang

\begin{tabular}{clll}
\hline No & \multicolumn{1}{c}{ Jenis Pakan Ayam } & \multicolumn{1}{c}{ Jenis Pakan Ayam } & KG/SAK \\
\hline 1 & 311 & DOC & $50 \mathrm{KG}$ \\
2 & $\mathrm{~N} 311$ & DOC & $50 \mathrm{KG}$ \\
3 & 321 & DOC Layer & $50 \mathrm{KG}$ \\
4 & 511 & Broiler & $50 \mathrm{KG}$ \\
5 & 512 & Broiler & $50 \mathrm{KG}$ \\
6 & $\mathrm{~N} 511$ & Broiler & $50 \mathrm{KG}$ \\
7 & $\mathrm{~N} 512$ & Broiler & $50 \mathrm{KG}$ \\
8 & $\mathrm{~N}-582$ & Afkir & $50 \mathrm{KG}$ \\
9 & 122 & Konsentrat Layer & $50 \mathrm{KG}$ \\
10 & 124 & Konsentrat Layer & $50 \mathrm{KG}$ \\
11 & BRAVO 124 & Konsentrat Layer & $50 \mathrm{KG}$ \\
13 & B-311 & Broiler & $50 \mathrm{KG}$ \\
14 & B-511 & Broiler & $50 \mathrm{KG}$ \\
15 & B-512 & Broiler & $50 \mathrm{KG}$ \\
16 & A201C & Broiler & $50 \mathrm{KG}$ \\
17 & 201 & Broiler & $50 \mathrm{KG}$ \\
18 & $200 \mathrm{C}$ & Broiler & $50 \mathrm{KG}$ \\
19 & $801 \mathrm{M}$ & Konsentrat Layer & $50 \mathrm{KG}$ \\
20 & BR 01 & Broiler & $50 \mathrm{KG}$ \\
\hline
\end{tabular}

\section{b). Harga}

Harga merupakan salah satu alat yang digunakan perusahaan untuk mencapai sasaran pemasarannya. Harga menurut Swastha dan Sukotjo (1993) adalah sejumlah uang (ditambah beberapa barang kalau mungkin) yang dibutuhkan untuk mendapatkan sejumlah kombinasi dari barang beserta pelayannya. Dibandingkan dengan bauran pemasaran lainnya (produk, distribusi, promosi) yang membutuhkan pengeluaran dana dalam jumlah besar, harga merupakan satu-satunya elemen bauran pemasaran yang mendatangkan pendapatan.

Dalam penentuan harga harus dapat menutup semua ongkos, atau bahkan lebih baik dari itu, yaitu untuk mendapatkan laba. Persaingan pasar juga dapat mempengaruhi penentuan harga. Dalam hal ini Rajawali Feed Centre berada dalam persaingan sempurna/persaingan murni (pure competition) dimana penjual yang berjumiah banyak aktif menghadapi pembeli yang banyak pula.

Harga pakan ayam pada Rajawali Feed Centre ini telah ditetapkan oleh produsen yaitu PT. Charoen Pokphand untuk harga jual pada konsumen Rajawali Feed Centre menetapkan sendiri sesuai dengan daerah pemasarannya berdasarkan jauh dekatnya jarak pelanggan. Dalam penetapan harga Rajawali Feed Centre juga tetap memperhatikan harga pasaran, Rajawali Feed Centre memilih untuk menetapkan harga yang bersaing karena tingkat persaingan untuk produk pakan ayam sudah cukup rumit.

\section{c). Sistem Distribusi}

Dalam kegiatan pemasaran suatu produk berupa barang maupun jasa unsur distribusi memegang peranan yang cukup penting dalam proses penyampaian barang dan jasa dari produsen ke konsumen akhir. Walaupun mutu suatu barang yang 
dihasilkan oleh suatu perusahaan baik dan bagus, tanpa ditunjang dengan sistem distribusi yang baik dan terpadu tidak akan membuat produk tersebut dapat bertahan dan diterima oleh pasar. Oleh karena itu sebelum meluncurkan produk ke pasar perusahaan harus terlebih dahulu merancang dan mempersiapkan sistem distribusi yang cocok baik dari segi saluran yang dipakai dan perantara yang digunakan.

Swastha dan Sukotjo (1999) menjelaskan bahwa suatu barang dapat berpindah tangan sejak dari produsen sampai ke konsumen. Ada beberapa saluran distribusi yang dapat digunakan untuk menyalurkan barangbarang yang ada, biasanya distribusi untuk barang konsumsi mempunyai lima saluran sebagai berikut :

1. Produsen $\rightarrow$ Konsumen

2. Produsen $\rightarrow$ Pengecer $\rightarrow$ Konsumen

3. Produsen $\rightarrow$ Pedagang besar $\rightarrow$ Pengecer $\rightarrow$ Konsumen

4. Produsen $\rightarrow$ Agen $\rightarrow$ Konsumen

5. Produsen $\rightarrow$ Agen $\rightarrow$ Pedagang besar $\rightarrow$ Pengecer $\rightarrow$ Konsumen

Menurut penelitian sebelumnya oleh Gustini (2005) Rajawali Feed Centre Padang dalam memasarkan produknya (pakan ayam) menggunakan dua saluran distribusi, yaitu saluran tingkat nol (langsung) dan saluran tingkat satu (menggunakan pengecer). Dari hasil penelitian tersebut juga didapatkan bahwa terdapat hubungan yang erat antara distribusi dengan penjualan seperti disebutkan oleh Gustini (2005) bahwa antara biaya distribusi dan penjualan mempunyai hubungan yang kuat dan positif, maksudnya dengan kenaikan biaya distribusi akan meningkatan volume penjualan. Hal ini ditunjukkan dari hasil penelitiannya yang menyebutkan bahwa kontribusi biaya distribusi terhadap peningkatan volume penjualan sebesar $99,4 \%$, dan sebesar $0,6 \%$ dipemgaruhi oleh faktor tain.

Ditinjau dari pihak produsen, kedudukan pedagang pengecer merupakan bidang keahlian dalam penjualan, sedangkan dari sisi konsumen merupakan agen pembeli dan yang menyediakan barang bagi konsumen. Sehingga dengan kegiatan pedagang pengecer menghimpun benda/barang yang diinginkan konsumen pada suatu tempat/lokasi tertentu, maka memungkinkan konsumen dapat memperoleh berbagai macam barang dalam jumlah sedikit, waktu yang cepat tanpa banyak rintangan (Atmakusuma, 1998).

Pengecer yang digunakan adalah toko-toko yang mudah dijangkau oleh konsumen yang ada pada daerahdaerah pemasaran dari Rajawali Feed Centre Padang. Dalam meningkatkan penjualannya Rajawali Feed Centre sebaiknya menambah jumlah pengecer - pengecer diberbagai daerah di Sumatera Barat. Luasnya daerah pemasaran yang dilayani perusahaan memberi kesempatan untuk meningkatkan penjualannya sekaligus pangsa pasarnya.

\section{d). Promosi}

Konsep menjual menyatakan bahwa konsumen, jika diabaikan, biasanya tidak akan membeli produk organisasi/perusahaan dalam jumlah yang cukup. Karena itu, organisasi /perusahaan harus melakukan usaha penjualan dan promosi yang agresif. Promosi merupakan suatu ungkapan dalam arti luas tentang kegiatankegiatan yang secara aktif dilakukan oleh perusahaan untuk mendorong konsumen membeli produk yang ditawarkan.

Usaha pemasaran pakan Rajawali Feed Centre setiap tahunnya 
mengadakan kegiatan promosi. Promosi lebih bertujuan untuk memberikan informasi pada pengecer dan konsumen tentang produk-produk yang tersedia, yang didapatkan dari pemasok yaitu Charoen Pokphan. Bentuk promosinya biasa menggunakan spanduk, bentuk lainnya adalah hadiah yang berupa jam dinding, payung, dan sebagainya untuk pembelian barang dalam jumlah tertentu. Sistem kupon yang berupa bonus barang yang sama bagi pengumpulan 10 kupon.

Promosi yang dilakukan perusahaan bertujuan disamping untuk memperkenalkan produk yang dihasilkan juga mengingatkan dan memberi pengetahuan kepada konsumen yang sudah ada maupun konsumen potensial tentang perusahaan dan produk yang ditawarkan sehingga konsumen tertarik untuk mengkonsumsinya. Dengan adanya promosi ini diharapkan konsumen akan selalu mengingat produk yang pemah dibeli sehingga akhimya dapat meningkatkan penjualan perusahaan.

\section{Kesimpulan}

1. Kinerja perusahaan dilihat dari kinerja keuangan menunjukkan keadaan yang baik, rata-rata hasil rasio berada diatas standar keuangan yang berlaku, kecuali rasio solvabilitas. Hal ini terjadi karena perusahaan menerapkan kebijakan uang kas yang ada di perusahaan hanya untuk operasional perusahaan, selebihnya diinvestasikan pada aktiva /persediaan. Perusahaan berada pada posisi yang likuid dimana Current Rasio dan Quick Rasio pada perusahaan bernilai besar diatas ukuran standar yaitu sebesar $298,13 \%$ dan $111,80 \%$. Rasio
Solvabilitas $23,20 \%$ namun rasio modal sendiri dengan aktiva tetap menunjukkan nilai besar dari nilai standar yaitu $500 \%$ yang menyatakan bahwa perusahaan cukup solvabel dalam memenuhi kewajibannya saat likuid. Hasil perhitungan yang diperoleh bahwa didapatkan keseluruhan perputaran aktiva ini selama setahun adalah 23,20 kali.

2. Kinerja Manajemen, pada umumnya sudah dijalankan cukup baik walaupun masih perlu perbaikan di setiap aspek, baik teknis, sumberdaya manusia dan pemasaran.

3. Usaha pemasaran pakan ayam Rajawali Feed Centre prospektif untuk dikembangkan setelah memperhatikan kinerja keuangan dan manajemen yang dilakukan perusahaan antara lain terlihat dari rasio-rasio keuangan dan dengan adanya perkembangan daerah pemasaran, mekanisme pemesanan pakan kepada pemasok yang telah diperhitungkan dengan cukup baik.

\section{Daftar Pustaka}

Assauri, S, 1999. Manajemen Produksi Dan Operasi. LPFEUI, Jakarta.

Atmakusuma, Yuniar, 1998. Tataniaga Peternakan, Universitas Terbuka. Depdibud, Jakarta.

Badan Pusat Statistik, 2004. Padang dalam Angka Tahun 2000 2004, Padang.

Boyd, Harper W, 2000. Manajemen Pemasaran, Penerbit Erlangga, Jakarta. 
Dessler, Gary, 1997. Manajemen Sumber Daya Mamusia, Prenhallindo, Jakarta.

Downey, David W dan Erickson, Steven. P, 1992. Manajemen Agribisnis, Penerbit Erlangga, Jakarta.

Gitosudarmo, Indriyo 2001. Pengantar Bisnis, edisi 2, BPFE Yogyakarta, Yogyakarta.

Gustini, Sri, 2006. Kebijakan Distribusi Dalam Meningkatkan Volume Penjualan Pakan Ayam (Studi Kasus Pada Rajawali Feed Centre Padang), Skripsi S1, Fakultas Peternakan Universitas Andalas, Padang.

Harahap, Sofyan Syafri, 2002. Teori Akuntansi : Laporan Keuangan, Bumi Aksara, Jakarta.

Kadarsan, H, 1995. Keuangan Pertanian dan Pembiayaaan Perusahaan Agribisnis, PT. Gramedia, Jakarta.

Kartadisastra, H.R, 1994. Pengelolaan Pakan Ayam, Kanisius, Yogyakarta.
Kotler, P, 1997. Manajemen Pemasaran, PT Prenhallindo, Jakarta.

Munawir, 1995. Analisa Laporan Kenangan, Liberty, Yogyakarta, Edisi IV.

Rasyaf, M, 1994. Makanan Ayam Broiler, Penerbit Kanisius, Jakarta.

Ruky, Akhmad, 2001. Sistem Manajemen Kinerja, PT. Gramedia Pustaka Utama, Jakarta.

Swasta, Basu dan Ibnu, Sukotjo. 1993. Pengantar Agribisnis Modern, Gadjah Mada. University Press, Yogyakarta.

Tjiptono F, 2002. Strategi Pemasaran, Andi, Yogyakarta.

Umar, H, 1997. Riset Akuntansi, PT. Gramedia Pustaka Utama, Jakarta.

2002. Evaluasi Kinerja Perusahaan, PT. Gramedia Pustaka Utama, Jakarta.

Wahyudi, Agustinus Sri, 1996. Manajemen Strategik, Binarupa Aksara, Jakarta.

Alamat Korespondensi: Fitrini, Sp

Jurusan Produksi Ternak

Fakultas Peternakan, Universitas Andalas

Kampus Limau Manis, Padang

Artikel diterima 15 September 2006, disetujui 10 Oktober 2006 